NOTE

\title{
Satellite telemetry suggests high levels of fishing-induced mortality in marine turtles
}

\author{
Graeme C. Hays ${ }^{1, *}$, Annette C. Broderick ${ }^{1}$, Brendan J. Godley ${ }^{1}$, Paolo Luschi ${ }^{2}$, \\ Wallace J. Nichols ${ }^{3}$

\begin{abstract}
${ }^{1}$ School of Biological Sciences, University of Wales Swansea, Singleton Park, Swansea SA2 8PP, UK
${ }^{2}$ Dipartmento di Etologia, Ecologia, Evoluzione, University of Pisa, Via A. Volta 6, 56126 Pisa, Italy

${ }^{3}$ Department of Herpetology, California Academy of Sciences, PO Box 752, Brookdale, California 95007, USA
\end{abstract}

\begin{abstract}
Long-term records of nesting numbers, or proxies to nesting numbers, show a precipitous decline in the size of many sea turtle populations. Population declines are most frequently attributed to fisheries bycatch, although direct quantification of this level of mortality is rare. We used satellite-tracking records for turtles in the Mediterranean Sea and Pacific, Atlantic and Indian Oceans to identify when turtles had been captured. Evidence for capture came from a combination of an increase in good quality locations from transmitters, transmitters moving inland to coastal towns and villages, and on-board submergence data, showing that transmitters had come out of the water. A high level of mortality was calculated, confirming current concerns regarding the outlook for sea turtles.
\end{abstract}

KEY WORDS: Argos $\cdot$ Chelonia $\cdot$ Dermochelys $\cdot$ Global $\cdot$ Fishery bycatch $\cdot$ Albatross

Resale or republication not permitted without written consent of the publisher

\section{INTRODUCTION}

Some sea turtle populations may soon become extinct due to human activities (Crowder 2000, Spotila et al. 2000). In particular, it has been noted worldwide that fishing activities can lead to turtle mortality (e.g. Robins 1995, Pandav et al. 1997), although direct quantification of the magnitude of this problem is difficult because of incomplete reporting. Certainly some specific fishing activities have been the cause for high profile concern. For example, along the eastern seaboard of the USA it was estimated that until the implementation of protection measures, thousands of turtles were being killed annually by shrimp trawlers (Lutcavage et al. 1997). More recently there has been great concern about the decline of leatherback turtle Dermochelys coriacea populations in the Pacific, which is thought to have been caused by high mortality of adults in oceanic long-line and gillnet fisheries (Eckert \& Sarti
1997, Crowder 2000, Spotila et al. 2000). Despite these concerns over the levels of fishing bycatch, direct quantification of this level of mortality is not straightforward.

One general approach to this type of ecological problem is to estimate mortality rates from radiotracking data, where the total tracking days are recorded as well as the number of individuals dying (Krebs 1989). With the advent of new technology this same approach has been applied to satellite-tracked individuals (Combreau et al. 2001). Since the latter approach requires large sample numbers of individuals to be tracked, and the cost of satellite-tracking is invariably high, mortality rate estimates from satellitetracking data are beyond the budgets of most individual projects. Our different studies in recent years have satellite-tracked marine turtles in several ocean basins, covering a range of species and different habitats, including periods of open-ocean migration, along-shore 
migration and residence in coastal areas (presumably feeding home-ranges) (Papi et al. 1997, Luschi et al. 1998, Nichols et al. 2000). While the primary original objective of these studies was to identify the movements of turtles and the routes followed during longdistance migration, we also obtained evidence for the mortality of some of the tracked individuals. This paper describes the pooled results from these satellitetracking projects, considers the evidence of fisheries bycatch from satellite transmitters and provides annual mortality rate estimates for the turtles in question.

\section{MATERIALS AND METHODS}

We satellite-tracked adult marine turtles around the world using Argos transmitters attached to the carapace. As well as providing the geographical location, the transmitter detected submergence patterns (time and duration) via a salt-water switch (Hays et al. 1999). The salt-water switch consisted of a pair of metal screws emerging from the transmitter. When submerged, seawater completed an electrical circuit between the screws. The times when this circuit was completed (i.e. the transmitter was submerged) and when it was not completed (i.e. the transmitter was at the surface or ashore) were recorded and relayed via the Argos system.

Turtles were tracked for varying lengths of time, until cessation of transmitter signals. Presumably, most of these cases reflected failure of the transmitters or battery depletion. In some cases, however, there was unusual telemetry from transmitters, suggesting turtles had been captured by fishermen. The following evidence supported this view: (1) sudden movement of tracked turtles to inland villages and towns and/or (2) sudden increase in the rate of good quality locations received (i.e. Location Classes 1, 2 and 3, which are generally within $1 \mathrm{~km}$ of the true position), indicating that the transmitters were no longer submerged (which prevents signals being transmitted) and/or (3) direct information from submergence sensors (the salt-water switch) on-board the transmitter, indicating the turtles were no longer submerging.

We used the Trent \& Rongstad (1974) estimator of the mortality rates, where $S=$ daily survival rate and $M=$ annual mortality rate:

$$
\begin{gathered}
S=1-\frac{\text { number of deaths }}{\text { total tracking days }} \\
M=1-S^{365.25}
\end{gathered}
$$

Confidence limits on this estimate were calculated using the variance for a binomial distribution, i.e. variance of $S=[S(1-S)] / \mathrm{n}$, where $\mathrm{n}=$ the number tracking days.

\section{RESULTS}

In a total of 5923 tracking days ( $\mathrm{n}=50$ turtles), there were 6 instances where the satellite telemetry data suggested a turtle had been captured (Table 1, Fig. 1). This was supported by direct observations in fishing villages that in 3 of the 6 cases, turtles were dead: 1 leatherback on the Kai Islands, Indonesia, and 1 loggerhead and 1 green turtle in Baja, California, USA. The remaining 3 inferred turtle mortalities involved 1 loggerhead tracked crossing the North Pacific from California to near Japan, 1 loggerhead tracked moving along the eastern seaboard of Africa from South Africa to Tanzania, and 1 leatherback tracked off South Africa. In none of the 3 cases was the death of the turtle confirmed.

In our calculations, total tracking days did not include the period after the transmitter came out of the water. These calculations yield an annual mortality rate of $M=0.31$ (95\% CI $=0.07-0.49)$ (Fig. 2). The relatively high confidence interval is a consequence of $S$ being so close to 1 , meaning a tiny error in the estimate

Table. 1. Green turtle Chelonia mydas, loggerhead turtle Caretta caretta, leatherback turtle Dermochelys coriacea. Satellitetracking data compiled for mortality estimates. GT, LT, Let = green turtles, loggerhead and leatherback turtles, respectively. $\mathrm{n}=$ no. of turtles; TTD = total tracking days; no. died = no. of tracks ending in fishing-induced mortality

\begin{tabular}{|llrrll|}
\hline Study no. & Species, location & $\mathrm{n}$ & TTD & No. died & \\
\hline 1 & GT, South China Sea & 5 & 335 & 0 & Source \\
2 & GT, Mediterranean Sea & 3 & 803 & 0 & Godley et al. (2002) \\
3 & GT, Eastern Pacific & 10 & 697 & 2 & W. J. Nichols (unpubl.) \\
4 & GT, Equatorial Atlantic & 13 & 773 & 0 & Luschi et al. (1998), Hays et al. (2002, unpubl.) \\
5 & LT, Indian Ocean & 9 & 1385 & 1 & Papi et al. (1997), Luschi et al. (2003, unpubl.) \\
6 & LT, Pacific Ocean & 2 & 919 & 1 & Nichols et al. (2000, unpubl.) \\
7 & Let, Indian Ocean & 7 & 1004 & 1 & Hughes et al. (1998, unpubl.) \\
8 & Let, Pacific Ocean & 1 & 7 & 1 & W. J. Nichols (unpubl.) \\
\hline
\end{tabular}




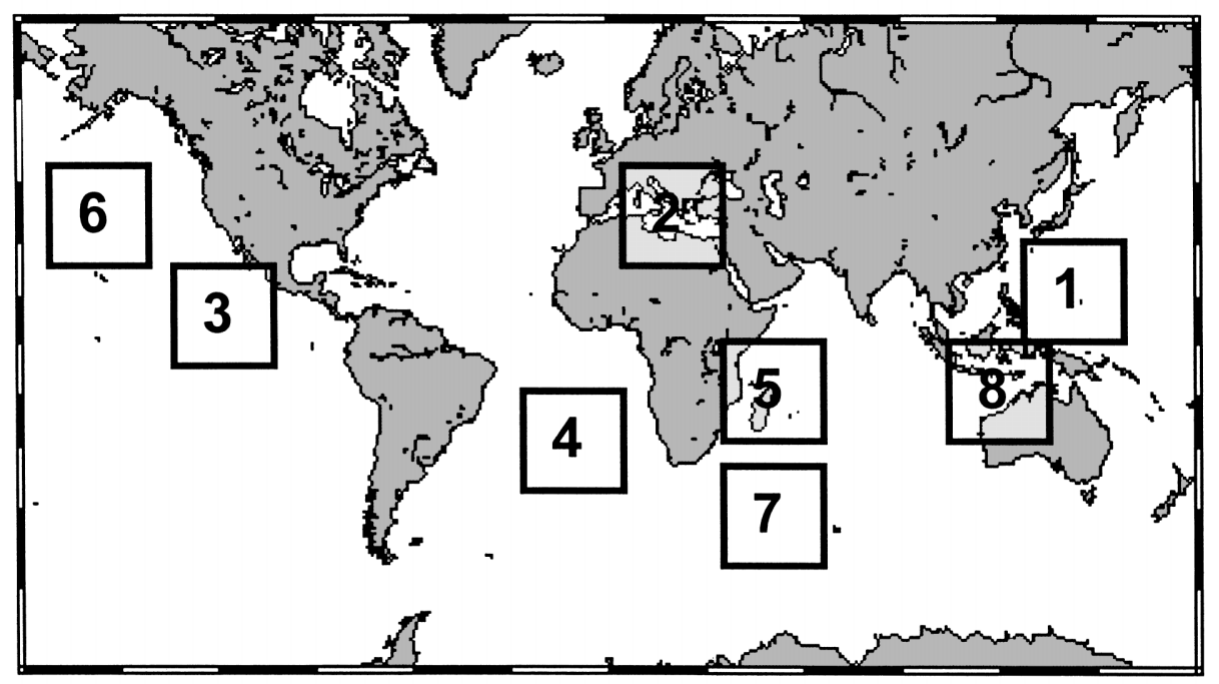

Fig. 1. Locations of turtle-tracking studies. Numbers show approximate position of each tracking study referred to in Table 1. Total tracking days and number of tracks ending in fishing-induced mortality were: $1=335 \mathrm{~d}_{1} 0 \mathrm{died}$; $2=803 \mathrm{~d}$, 0 died; $3=697 \mathrm{~d}, 2$ died; $4=773 \mathrm{~d}, 0$ died; $5=1385 \mathrm{~d}, 1$ died; $6=919 \mathrm{~d}, 1$ died; $7=1004 \mathrm{~d}, 1$ died; $8=7 \mathrm{~d}, 1$ died

of $S$ would produce a large change in the value of $M$. We explored how this confidence interval would change with larger sample sizes. Assuming that $M=$ 0.31 , as the total number of tracking days increases to 50000 , the $95 \%$ confidence interval for $M$ will be reduced to $0.24-0.38$ (Fig. 2).

\section{DISCUSSION}

Radio-tracking is a standard tool for estimating mortality rates of tracked turtles. Satellite-tracking, because of its global coverage, improves on this method, estimating mortality in species that may move large distances. However, it is clearly important to be able to identify when a tracked individual has died. It has been suggested that merely the loss of transmissions from a satellite-tracked individual may provide some index of the level of mortality (Polovina et al. 2000). While this approach may be of some use in identifying differences in mortality levels between different groups of animals, it is likely to overestimate the absolute levels of mortality, as satellite transmitters cease to transmit for many other reasons than simply mortality of the tracked individuals (Plotkin 1998).

It is more informative if data relayed via a satellite system can specifically indicate mortality. For example, Combreau et al. (2001) used several criteria, including temperature and activity data relayed via transmitters, to ascertain mortality of satellite-tracked houbaru bustards. Similarly, our approach involved the temporal pattern of locations, Argos location class and on-board submergence data to identify mortality events. In most cases, this approach is inevitably inferential, since direct reports of dead turtles are rare. Indeed, if all the turtles killed by humans were reported, then there would be no need to use satellite telemetry to estimate mortality rates.

It is possible that satellite transmitters are removed by fishermen, the turtles released and the transmitter taken ashore. However for hard-shelled species, we

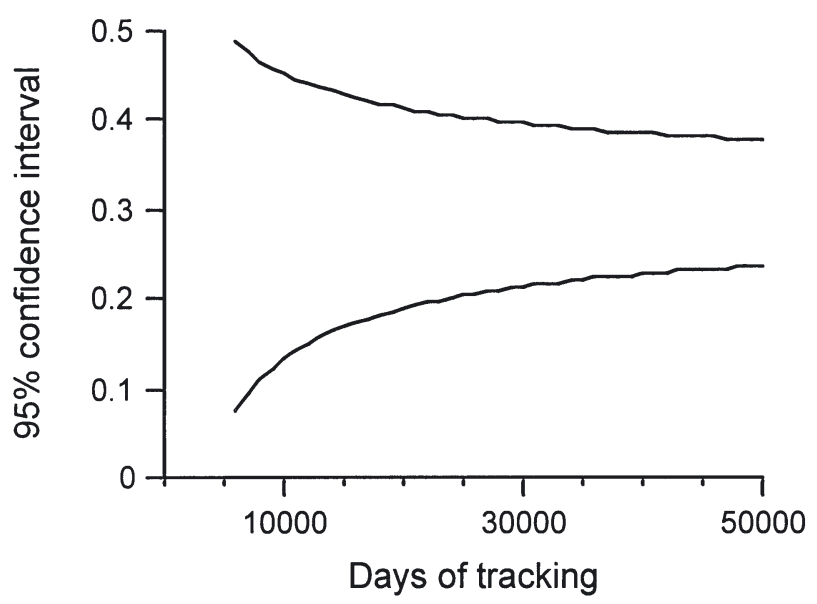

Fig. 2. Confidence interval (95\%) for the annual mortality rate $(M)=0.31$, given different sample sizes for the total tracking days. We had a total of 5923 tracking days and the $95 \%$ CI of $M$ was $0.07-0.49$. If, in a hypothetical situation, tracking days increased to 50000 and a comparable mortality rate was recorded, the $95 \%$ CI would decrease to $0.24-0.38$ 
attached the transmitter using very strong epoxy to make its removal difficult. Furthermore, in 3 cases dead turtles were observed with transmitters still attached. We are therefore confident that our inference of fishing-induced mortality was indeed correct. One should also bear in mind that we may have missed some cases of fisheries-bycatch. Although Argos provides global coverage, the satellites are not in the transmitters' 'sight' all the time-there is a finite number of satellite overpasses, typically around 10 to $30 \mathrm{~d}^{-1}$ depending on latitude, with intervals of $1 \mathrm{~h}$ or more when no satellite overpass takes place (for more information see www.argosinc.com/). Therefore it is possible that during these intervals, a turtle might be captured by fishermen and the transmitter discarded into the sea or brought on board a ship or into a building, meaning that signals indicating the death of the turtle are not received.

For adult turtles, previous mortality estimates have mostly been based on counting and identifying female turtles on nesting beaches. By tagging individuals while they are nesting and then re-identifying them in subsequent years, an estimate of the annual mortality rate can be determined. This approach is, to some extent, limited by tag loss and also by turtles not being resighted even when they have returned to nest, leading to maximum mortality estimates being produced. Bjorndal (1980) used mark-recapture techniques to estimate the annual mortality for adult female green turtles nesting in Costa Rica to be 0.39 between 1959 and 1978, consistent with high captures of turtles by fishermen. Along the east coast of the USA, a similar approach has produced estimates of annual mortality rates for adult turtles of about 0.2 (National Marine Fisheries Service 2001). Spotila et al. (2000) used implanted PIT tags to identify individuals and conducted intensive beach patrols to locate almost all the nesting individuals. In this way they estimated that the annual rate of mortality for leatherback turtles nesting on the Pacific coast of Costa Rica was around 0.34, a level that could lead to the rapid extinction of this population (Spotila et al. 2000). Viewed in the context of these results, our estimate of turtle annual mortality rates derived from satellite transmitters $(M=0.31)$ is not surprising and confirms that fisheries bycatch is a pressing concern.

One of the key assumptions when using radio or satellite telemetry to estimate mortality rates is that the transmitter itself does not affect an animal's survival (e.g. Winterstein et al. 2001). Some types of equipment attached to turtles have directly contributed to an increased mortality rate, e.g. plastic flipper tags, which become entangled in fishing nets and thus raise the chances of turtle mortality (Nichols \& Seminoff 1998, Suggett \& Houghton 1998). Therefore, to minimise the chance that satellite tags will become snagged in fishing gear, the epoxy used for attachment is streamlined to provide a smooth hydrodynamic shape, and there is little protruding from the attachment that could become snagged. Furthermore, at least for the eastern Pacific, high mortality levels are evident from direct assessments of dead turtles in fishing villages (Gardner \& Nichols 2001)

Regional variations in turtles mortality might be expected, for example, due to fishing techniques and fishing intensity. Similarly, species-specific patterns might also be expected, due to differences in habitats and depth distributions of the various species (Polovina et al. 2003). However, given that we only have small sample sizes for each region and species, we feel it would be too speculative to estimate regional and speciesspecific mortality rates at this stage. Certainly for green turtles at Ascension Island, a recent estimate of the annual number of nests gave comparable numbers to those recorded 25 yr previously (Godley et al. 2001) suggesting that this population is probably not in decline. In contrast, many nesting populations in the Pacific have shown long-term declines, reinforcing the concern for the conservation of this species (Limpus 1995). We therefore do not suggest that an annual mortality rate of 0.31 applies universally across regions and species. Rather, our main aims with this study are to introduce the concept of using satellite telemetry to identify mortality in sea turtles; to show, in the most general of ways, that mortality rates for this group are high; and finally, to find a way forward for collaboration between different research groups, so that regional and species-specific mortality estimates can be derived from satellite-tracking studies. Once regionally specific mortality rate estimates have been obtained, comparisons with regional fishing effort will then be possible along the lines of studies already conducted with albatrosses, another group suffering heavy fisheries bycatch (Weimerskirch et al. 1997, Hyrenbach \& Dotson 2003). Even with the limited data currently available, the strongest message from this initial study is that adult turtles are experiencing high levels of fishery bycatch, highlighting the need for increased protection.

Acknowledgements. We thank Melissa Snover for comments on earlier drafts of the manuscript, George Hughes for assistance with fieldwork in South Africa and all the many individuals and organisations that contributed to the projects referred to in this study.

\section{LITERATURE CITED}

Bjorndal KA (1980) Demography of the breeding population of the green turtle, Chelonia mydas, at Tortuguero, Costa Rica. Copeia 1980:525-530

Combreau O, Launay F, Lawrence M (2001) An assessment of 
annual mortality rates in adult-sized migrant houbaru bustards (Chlamydotis [undulata] macqueenii). Anim Conserv 4:133-141

Crowder L (2000) Leatherback's survival will depend on an international effort. Nature 405:881

Eckert SA, Sarti L (1997) Distant fisheries implicated in the loss of the world's largest leatherback nesting population. Mar Turtle Newsl 78:2-7

Gardner SC, Nichols WJ (2001) Assessment of sea turtle mortality rates in Bahía Magdalena region, Baja California Sur, Mexico. Chelonian Conserv Biol 4:197-199

Godley BJ, Broderick AC, Hays GC (2001) Nesting of green turtles (Chelonia mydas) at Ascension Island, South Atlantic. Biol Conserv 97:151-158

Godley BJ, Richardson S, Broderick AC, Coyne MS, Glen F, Hays GC (2002) Long-term satellite telemetry of the movements and habitat utilisation by green turtles in the Mediterranean. Ecography 25:352-362

Hays GC, Luschi P, Papi F, del Seppia C, Marsh R (1999) Changes in behaviour during the internesting period and postnesting migration for Ascension Island green turtles. Mar Ecol Prog Ser 189:263-273

Hays GC, Broderick AC, Godley BJ, Lovell P, Martin C, McConnell BJ, Richardson S (2002) Bi-phasal long-distance migration in green turtles. Anim Behav 64:895-898

Hughes GR, Luschi P, Mencacci R, Papi F (1998) The 7000-km oceanic journey of a leatherback turtle tracked by satellite. J Exp Mar Biol Ecol 229:209-217

Hyrenbach KD, Dotson RC (2003) Assessing the susceptibility of female black-footed albatross (Phoebastria nigripes) to longline fisheries during their post-breeding dispersal: an integrated approach. Biol Conserv 112:391-404

Krebs CJ (1989) Ecological methodology. Harper Collins, New York, NY

Limpus CJ (1995) Global overview of the status of marine turtles: a 1995 viewpoint. In: Bjorndal KA (ed) The biology and conservation of sea turtles, revised edition. Smithsonian Institution Press, Washington, DC, p 605-609

Luschi P, Papi F, Liew HC, Chan EH, Bonnadonna F (1996) Long-distance migration and homing after displacement in the green turtle (Chelonia mydas): a satellite-tracking study. J Comp Physiol 178A:447-452

Luschi P, Hays GC, del Seppia C, Marsh R, Papi F (1998) The navigational feats of green sea turtles migrating from Ascension Island investigated by satellite telemetry. Proc R Soc Lond B 265:2279-2284

Luschi P, Sale A, Mencacci R, Hughes GR, Lutjeharms JRE, Papi F (2003) Current transport in leatherback sea turtles (Dermochelys coriacea) wandering in the ocean. Proc R Soc Lond B(Suppl)2 (DOI 10.198/rsbl.2003.0036)

Lutcavage ME, Plotkin P, Witherington B, Lutz PL (1997) Human impacts on sea turtles survival. In: Lutz PL, Musick JA (eds) The biology of sea turtles. CRC Press, Boca Raton, FL, p 387-409

Editorial responsibility: Otto Kinne (Editor), Oldendorf/Luhe, Germany
National Marine Fisheries Service (2001) Stock assessments of loggerhead and leatherback sea turtles and an assessment of the impact of the pelagic longline fishery on the loggerhead and leatherback sea turtles of the Western North Atlantic. US Department of Commerce NOAA Technical Memorandum NMFS-SEFSC-455: $1-343$

Nichols WJ, Seminoff JA (1998) Plastic 'Rototags' may be linked to sea turtle bycatch. Mar Turtle Newsl 79:20-21

Nichols WJ, Resendiz A, Seminoff JA, Resendiz B (2000) Transpacific migration of a loggerhead turtle monitored by satellite telemetry. Bull Mar Sci 67:937-947

Pandav B, Choudhury BC, Kar CS (1997) Mortality of Olive Ridley turtles Lepidochelys olivacea due to incidental capture in fishing nets along the Orissa coast, India. Oryx 31:32-36

Papi F, Luschi P, Crosio E, Hughes GR (1997) Satellitetracking experiments of the navigational ability and migratory behaviour of the loggerhead turtles Caretta caretta. Mar Biol 129:215-220

Plotkin PT (1998) Interaction between behavior of marine organisms and the performance of satellite transmitters: a marine turtle case study. Mar Technol Soc J 32:5-10

Polovina JJ, Kobayashi DR, Parker DM, Seki MP, Balazs GH (2000) Turtles on the edge: movement of loggerhead turtles (Caretta caretta) along oceanic fronts, spanning longline fishing grounds in the central North Pacific, 1997-1998. Fish Oceanogr 9:71-82

Polovina JJ, Howell E, Parker DM, Balazs GH (2003) Divedepth distribution of loggerhead (Caretta caretta) and olive ridley (Lepidochelys olivacea) sea turtles in the central North Pacific: might deep longline sets catch fewer turtles? Fish Bull 101:189-193

Robins JB (1995) Estimated catch and mortality of sea turtles from the east coast otter trawl fishery of Queensland, Australia. Biol Conserv 74:157-167

Spotila JR, Reina RD, Steyermark AC, Plotkin PT, Paladino FV (2000) Pacific leatherback turtles face extinction. Nature 405:529-530

Suggett DJ, Houghton JDR (1998) Possible link between sea turtle bycatch and flipper tagging in Greece. Mar Turtle Newsl 81:10-11

Trent TT, Rongstad OJ (1974) Home range and survival of cottontail rabbits in south-western Wisconsin. J Wildl Manag 38:459-472

Weimerskirch H, Brothers N, Jouventin P (1997) Population dynamics of wandering albatross Diomedea exulans and Amsterdam albatross $D$. amsterdamensis in the Indian Ocean and their relationships with long-line fisheries: conservation implications. Biol Conserv 79:257-270

Winterstein SR, Pollock KH, Bunck CM (2001) Analysis of survival data from radiotelemetry studies. In: Millspaugh JJ, Marzluff JM (eds) Radio tracking and animal populations. Academic Press, San Diego, CA, p 351-380

Submitted: June 16, 2003; Accepted: September 2, 2003

Proofs received from author(s): October 28, 2003 